\title{
Genetic Polymorphisms in the Histamine Receptor Family
}

\section{Stephany Micallef and Astrid Sasse}

School of Pharmacy and Pharmaceutical Sciences, Trinity Biomedical Sciences

Institute, Trinity College Dublin, Dublin 2, Ireland

Corresponding author: sassea@tcd.ie

Tel: +353-1-89602797 


\begin{abstract}
:
Histamine is a biogenic amine which has an inherent biological importance in many physiological functions, both in the central nervous system and in the periphery. With the new genomic era we are facing, personalised care and treatment is becoming one of the major focal points in research. This chapter focuses on the genetic variations and polymorphisms localised on genes encoding for human histamine receptors (HRHs) where it provides an up to date collection of polymorphisms found on genes encoding $\mathrm{HRHs}$ and their association to diseases. There is a clear need to highlight the specific implications polymorphisms have on this family of G-protein coupled receptors. This book chapter collates recent and other important publications related to polymorphisms and genetic linkage of histamine receptors. New association studies have been published for the gene encoding the HRH4, linking SNPs to asthma, cancer and atopic dermatitis. For example, rs17187619, rs527790, rs487202, rs1421125 and rs615283 have been associated with infection-induced in asthma patients. Other SNPs were found to harbour a link in breast cancer rs623590, rs11662595, rs1421125. With the increasing interest in cancer research, a polymorphism (rs2607474) discovered on the gene encoding for HRH2 was also found to have an association to gastric atrophy leading to gastric cancer. Looking into pharmacogenetics, a linkage was found between risperidone treatment and histamine receptor $3(\mathrm{HRH} 3)$, where rs3787430 could be a potential biological marker for treatment. With these significant genetic variations recently discovered and their potential contribution to the common diseases, this chapter gathers the knowledge to date for SNPs identified on the human histamine receptors.
\end{abstract}

Key words: Histamine receptors, genetic polymorphisms, single nucleotide polymorphisms, association studies, linkage analysis, human histamine 1 receptor, human histamine 2 receptor, human histamine 3 receptor, human histamine 4 receptor 
Single nucleotide polymorphisms can show an effect at a phenotypic level. In humans, these SNPs occur in at least $1 \%$ of the population with at a frequency of 1 every 100 to 300 bases along the 3 billion-base human genome [1]. Understanding the genetic basis of receptors generates better comprehension of underlying diseases leading to novel strategies for improved therapeutic agents. Hence, considering the biological significance of histamine, polymorphisms of histaminerelated genes represent potential genetic factors that are likely to influence a disease or a therapy. In this chapter we look into the genetic composition of the histamine receptor family and identify genetic variants associated with disorders and how they impact on gene function.

The oldest family members of the amine subtype are histamine $\mathrm{H}_{1}$ and histamine $\mathrm{H}_{2}$ receptors. They were the first histamine GPCRs discovered and they were first cloned in 1991 [2]. The existence of a third histamine receptor was known pharmacologically but the histamine $\mathrm{H}_{3}$ receptor was first cloned only in 1999, with the discovery that cells transfected with GPCR97 were able to inhibit adenylate cyclase in response to histamine [3]. Homology and phylogenetic analysis of the $\mathrm{H}_{3}$ receptor showed it to be markedly different from the previously cloned $\mathrm{H}_{1}$ receptor and $\mathrm{H}_{2}$ receptors, which suggests that these histamine receptors evolved from different ancestor sequences [2]. This discovery also led to the identification of a fourth receptor, the human histamine $\mathrm{H}_{4}$ receptor in the year $2000 / 2001$ by several research groups [4-10].

All four histamine receptors belong to the rhodopsin-like family of the G-protein coupled receptors [11]. Even though they form part of the same family, they exhibit different genomic and amino acid organization. Using the bioinformatics tool GenomeNet and multiple sequence alignment CLUSTALW, homology for the genes can be estimated. Comparing the DNA sequence alignment between all $\mathrm{HRH}$ genes the homology seems to be in the same range (18-20\%) between human histamine receptors (HRHs) (Table 1) [12].

Table 1

Gene and protein homology for the histamine receptor subtypes

\begin{tabular}{|c|l|c|c|c|c|}
\hline \multirow{2}{*}{$\begin{array}{c}\text { Homology for } \\
\text { HRHs }\end{array}$} & \multicolumn{4}{|c|}{ Gene \% } \\
\cline { 3 - 6 } & HRH1 & HRH2 & HRH3 & HRH4 \\
\hline \multirow{2}{*}{$\begin{array}{c}\text { HRH1 } \\
$\cline { 2 - 5 }\end{array}$)$} & & 18.60 & 20.20 & 20.60 \\
\cline { 2 - 6 } & HRH2 & 21.50 & & 20.70 & 18.95 \\
\cline { 2 - 6 } & HRH3 & 25.70 & 19.50 & & 18.30 \\
\cline { 2 - 6 } & HRH4 & 23.00 & 22.00 & 37.00 & \\
\hline
\end{tabular}


However, the translated genomic sequences for the HRH family into amino acids give a different picture. An amino acid sequence resemblance can be seen between two GPCR family members, namely the $\mathrm{H}_{3}$ receptor and the $\mathrm{H}_{4}$ receptor. The histamine $\mathrm{H}_{3}$ receptor displays a $37 \%$ homology to the $\mathrm{H}_{4}$ receptor, but when compared to $\mathrm{H}_{1}$ and $\mathrm{H}_{2}$ receptors the similarity drops to $23 \%$ and $22 \%$, respectively (Table 1) [12]. Looking at the transmembrane domains, the similarity between the $\mathrm{H}_{3}$ receptor and $\mathrm{H}_{4}$ receptor increases up to $54 \%$ and if the physiochemical properties of the amino acids is taken into account this similarity increases even more to $68 \%$ [13]. This similarity between the $\mathrm{H}_{3}$ receptor and $\mathrm{H}_{4}$ receptor also led to the development of imidazole-containing ligands that have a dual action on histamine $\mathrm{H}_{3}$ and histamine $\mathrm{H}_{4}$ receptors [14]. Similarly, ligands targeting $\mathrm{H}_{1}$ and $\mathrm{H}_{2}$ receptors were also investigated using a series of cyanoguanidines compounds were synthesized by linking mepyramine-type $\mathrm{H}_{1}$ receptor antagonist substructures with roxatidine-, tiotidine-, or ranitidine-type $\mathrm{H}_{2}$ receptor antagonist moieties [15]. However, these need to be further improved to provide an enhanced affinity binding profile. The combination of $\mathrm{H}_{1}$ and $\mathrm{H}_{4}$ receptor antagonists was also studied, where benefit was observed by inhibiting both receptors in histamine-induced scratching. This study suggested that combined $\mathrm{H}_{1}$ and $\mathrm{H}_{4}$ antagonists provided to be more effective than monotherapy [16]. The dual antagonistic benefit was also identified when the $\mathrm{H}_{1}$ antagonist, olopatadine, and $\mathrm{H}_{4}$ antagonist, JNJ17777120, were used in allergic dermatitis mice models. The combined effect proved to be as effective as prednisolone. Glucocorticoids such as prednisolone are known for atrophy of the skin and systemic side effects. The $\mathrm{H}_{4}$ antagonist is currently in phase II clinical study and is proving to have a safe drug profile [17]. These results indicate a promising future for the treatment of these allergic conditions.

Important cellular processes such as DNA binding, protein interactions and enzyme activity are highly impacted by conserved domains in proteins [18]. Alignment of the amino acid sequences of the GPCR family provides further evidence of the similarities and conserved domains between these receptors. Figure 1 represents the alignment of $\mathrm{H}_{1}$ and $\mathrm{H}_{2}$ receptors on the amino acid level. The dark grey highlights conserved amino acids between the two receptors, while the light grey regions represent strong similarities between conserved domains. The yellow highlight on the other hand represents the seven transmembrane domains of the GPCRs. Even though the homology is significant between these proteins, the $\mathrm{H}_{1}$ receptor is characterized by a large intracellular loop 3 (ICL3) unlike the receptor $\mathrm{H}_{2}$ receptor subtype, with a small ICL3 and a longer 
C-terminal. The asterisks $\left(^{*}\right)$ showed in Figure 1 represents amino acids which are singly fully conserved residue.

\section{[Figure 1]}

Figure 2 shows a similar representation for the newer histamine receptors, histamine $\mathrm{H}_{3}$ and $\mathrm{H}_{4}$ receptors; noticeably, both show a large intracellular loop 3 (ICL3), comparable to the ICL in histamine $\mathrm{H}_{1}$ receptor. GPCRs are known to interact with a wide variety of protein domains through the intracellular loops, transmembrane and C-terminal domains. The most abundant interaction is with the C-terminus of the GPCR [19]. Both histamine $\mathrm{H}_{3}$ and $\mathrm{H}_{4}$ receptors show a longer $\mathrm{C}$-terminus which is comparable to the histamine $\mathrm{H}_{1}$ receptor.

\section{[Figure 2]}

Studies on the crystalline structures of GPCRs identified common similarities between class A receptors. The extracellular loops $(E C L)$ are considered as peptide linkers that hold together functionally important transmembrane domains. This link also keeps these helices in a stable position in the cell membrane. The ECL have also the important role of receptor activation and ligand binding [20]. The first extracellular loop (ECL1) is generally small and made up of only a few amino acids. This is also represented in all 4 histamine receptors. Despite this, it was identified in different publications that the ECL1 affects the binding pockets, as with the help of other ECL this loop can provide rigidity and structure essential for receptor activation [20].

Histamine $\mathrm{H}_{1}$ receptor and $\mathrm{H}_{2}$ subtypes have proven to be excellent drug targets, and the more recently discovered histamine $\mathrm{H}_{3}$ and $\mathrm{H}_{4}$ receptors remain under investigation as future drug targets. First and second generation antihistamines are widely used to relief symptoms of allergic rhinitis, urticarial and other allergies and can cost between $\$ 8$ to $\$ 200$ per month per patient [21], hence the search for histamine ligands is appealing for the pharmaceutical industry. Ligands for histamine $\mathrm{H}_{3}$ receptor are currently in clinical studies. Antagonists for this receptor are currently in Phase 1 and Phase 2 clinical trials under review that indicate there is a potential treatment for Alzheimer's disease, ADHD, schizophrenia, epilepsy, narcolepsy, obesity, neuropathic pain and allergic rhinitis [22]. The histamine $\mathrm{H}_{3}$ receptor antagonist pitolisant is in Phase 3 clinical trial for treatment of narcolepsy and excessive daytime sleepiness associated with Parkinson's disease. The recently discovered $\mathrm{H}_{4}$ receptor is still undergoing intense preclinical research, with some 
novel $\mathrm{H}_{4}$ receptor antagonists having entered clinical trials, such as; UR-63325 which recently completed Phase 2 clinical trial for allergic rhinitis [23], JNJ-39758979 completing Phase 2 clinical trial for patients suffering from asthma and PF-3893787 which is in Phase 1 clinical trial for asthmatic patients subjected to allergen change [24].

\section{Human Histamine $\mathrm{H}_{1}$ Receptor}

The human histamine $\mathrm{H}_{1}$ receptor is the largest protein in the histamine receptor family [2] and is expressed primarily in smooth muscle, endothelial cells, the adrenal medulla, the heart, and also in the central nervous system (CNS). The $\mathrm{H}_{1}$ receptor is predominantly involved in smooth muscle contraction and increased vascular permeability [7]. The main therapeutic target for $\mathrm{H}_{1}$ receptor antagonists are allergic conditions and sleep disorders [4].

Histamine $\mathrm{H}_{1}$ gene $(\mathrm{HRH} 1)$ is located on chromosome 3; 3p25. Figure 3 shows the complete organisation of this receptor. In (A) the genomic organisation is seen where it is characterised by a large intron between the UTR region at the 5'-end and has only one exon [12]. The amino acid sequence of this receptor (B) in turn shows a large intracellular loop (ICL3) similar to the $\mathrm{H}_{3}$ and $\mathrm{H}_{4}$ receptor. The snake plot for the amino acid sequence is represented in (C) which illustrates the structural formation of the receptor [25].

[Figure 3]

\section{Histamine $\mathrm{H}_{1}$ receptor polymorphisms in CNS disorders}

The histamingergic system has proven to be one of the aminergic systems present in the mamalian CNS. The discovery that histamine is one of the major neurotransmitters in the CNS, encouraged studies that proved it is involved in a wide range of physiological functions such as cognition, emotion, feeding behavior and sleep-wake cycle [26]. Studies on schizophrenia observed that the levels of $\mathrm{N}$-tele-methylhistamine, a major brain histamine metabolite, were elevated in the cerebrospinal fluid of schizophrenia patients and $\mathrm{H}_{1}$ receptor binding sites were decreased [27-29]. The role of this receptor in psychiatric conditions was further evidenced by showing that antidepressants and antipsychotics exhibit a high binding affinity to $\mathrm{H}_{1}$ receptor with a very pronounced antagonistic effect [30]. High binding affinity to the $\mathrm{H} 1$ receptor in antidepressants has been linked to a higher incidence of metabolic syndrome in patients with 
bipolar disorder [31]. The histaminergic system may also be a target for the prevention of obesity and metabolic syndrome through histamine $\mathrm{H}_{1}$ and $\mathrm{H}_{3}$ receptors with combined activity compounds displaying agonism at $\mathrm{H}_{1}$ receptors and antagonism at $\mathrm{H}_{3}$ receptors [32].

Genetic variations in histamine $\mathrm{H}_{1}$ receptors were studied due to its interesting role in CNS disorders. Single nucleotide polymorphisms (SNPs) were found to play a role in depression in bipolar disorder, where the SNPs in the dopamine $\mathrm{D}_{3}$ receptor and histamine $\mathrm{H}_{1}$ receptor genes indicated a significant association to the improvement of the condition following olanzapine and fluoxetine treatment [33]. Studying SNP variations can also be of interest in predicting side effects of medications and developing personalized medicines. Antipsychotic medication such as clozapine and olanzapine are associated with an increased risk of obesity. Clozapine, the atypical antipsychotic, has a diverse binding profile to all four aminergic systems (serotonergic, dopaminergic, histaminergic and noradrenergic) [34]. A study on antipsychotic affinity for the histamine $H_{1}$ receptor and the muscarinic $M_{3}$ receptor has been linked to side effects such as weight gain. A significant association was also identified between patients using antipsychotics with high affinity for the $\mathrm{H}_{1}$ receptor (clozapine, olanzapine and quetiapine) in obesity and BMl; where haplotype for rs346074-rs346070 A-T associated with obesity $P=0.025$ and haplotype AT associated with BMI $P=0.005$ [35]. In another study, however, looking into a polymorphism on exon 1 which leads to a change in Glu349Asp on this receptor (which lies on ICL3), found no association for antipsychotic induced weight gain in a Chinese population diagnosed with schizophrenia [36].

Variations found on the promoter region of Histamine $\mathrm{H} 1$ Receptor were investigated for association for psychiatric disorders. A significant Linkage Disequilibrium (LD) $\left(P<10^{-6}\right)$ was found in the excess of $C$ allele but no strong association with schizophrenia was identified in multiple testing. However, the polymorphism for G/C allele may represent a marker for more functional polymorphisms located further upstream [37].

The histamine receptors are also of interest in Parkinson's disease patients (PD) as histamine is involved in neuronal degeneration and neurotoxicity. The expression and density of histamine receptors was observed to change in PD patients [38] and histamine receptor antagonists were noticed to improve motor symptoms. However, a study that looked into the a C/T polymorphism in Exon 1 which results in a Leu449Ser amino acid substitution was not able to link this SNP to PD [39]. 


\section{Histamine $H_{1}$ receptor polymorphisms in inflammation}

Histamine levels have been studied in various inflammatory diseases suggesting an association of these conditions to histamine receptors. Histamine levels are found to be elevated in bronchoalveolar fluids extracted from asthma patients, in the skin and plasma of patients with atopic dermatitis, in chronic urticaria biopsies, in both plasma and synovial fluid of patients with rheumatoid arthritis and in the plasma of patients with psoriatic arthritis [40]. The major receptors shown to be linked to inflammation and immune response are $\mathrm{H}_{1}, \mathrm{H}_{2}$ and $\mathrm{H}_{4}$ receptors [41]. Activation of $\mathrm{H}_{1}$ receptors increases histamine release and the release of other mediators, while also augmenting the pro-inflammatory activity of the immune system by promoting migration to the area of inflammation.

To date the $\mathrm{H}_{1}$ receptor has been the major target in the treatment of allergic conditions. Histamine $\mathrm{H}_{1}$ receptor antagonists have been used for decades to treat allergies, and although they provide symptomatic relief for most allergic conditions, they are not as effective for allergic asthma [42]. A study in a Korean population looked into associations between aspirin-induced urticarial/angioedema to polymorphisms on $\mathrm{H}_{1}$ receptor. The polymorphisms studied were a $\mathrm{C} / \mathrm{T}$ change in the promoter region and a G/A change in Exon 1 that leads to D349A amino acid change. However, no association was found between these genetic variations and the allergic response [43].

\section{Histamine $\mathrm{H}_{1}$ receptor polymorphisms in cancer}

The HRH1 gene was investigated for a potential link in various types of cancer. In a study conducted by Wang et al, 88 SNPs were identified that may cause an impact of histamine on $\mathrm{H}_{1}$ receptor. Out of these 88 SNPs, 84 led to a missense mutation and 4 alleles that disrupt an exon splicing enhancer. From 153 tests carried out on the HRH1 gene, 23 tests proved an association between microarray expression in the $\mathrm{HRH} 1$ gene and cancer prognosis (including bladder, blood, brain, breast, colorectal, eye, lung, ovarian, soft tissue cancers) with $5 \%$ level of significance. It is also worth noting that the level between $\mathrm{HRH} 1$ expression and the different types of cancer prognosis varied, suggesting that the function of $\mathrm{HRH} 1$ gene varies between cancers [44].

In a large population study to determine genetic variability, polymorphisms were selected to identify opioid efficacy in cancer patients. Experience has shown that opioid doses and efficacy vary in cancer patients and studies in small populations samples were not found to be reliable. This study conducted by Klepstad et al, included polymorphisms from $\mathrm{H}_{1}$ receptor (rs2606731 
rs346076 rs901865 rs346070). However, Opioid efficacy in cancer patients for pain is not genetically associated with these SNPs [45].

A summary of the above mentioned polymorphisms and their respective SNP location is shown in Table 2 below.

Table 2. HRH1 polymorphisms in diseases

\begin{tabular}{|c|c|c|c|c|}
\hline rs number & SNP & $\begin{array}{l}\text { Location } \\
\text { on gene }\end{array}$ & Condition & PubMed ID \\
\hline $\mathrm{NA}^{\dagger}$ & $\mathrm{G} / \mathrm{C}$ & $\begin{array}{l}\text { Promoter } \\
\text { (intron) }\end{array}$ & Schizophrenia & $\begin{array}{l}12429384 \\
{[37]}\end{array}$ \\
\hline $\begin{array}{l}\text { rs346074 } \\
\text { rs346070 }\end{array}$ & $\begin{array}{l}A / G \\
C / T\end{array}$ & $\begin{array}{l}\text { Intron } 1 \\
\text { 3' UTR }\end{array}$ & Schizophrenia & $\begin{array}{l}21336576 \\
{[35]}\end{array}$ \\
\hline rs2067467 & $\mathrm{G} / \mathrm{T}$ & Exon 1 & Schizophrenia & $\begin{array}{l}21937795 \\
{[36]}\end{array}$ \\
\hline rs2067470 & $\mathrm{C} / \mathrm{T}$ & Exon 1 & $\begin{array}{l}\text { Parkinson's } \\
\text { disease }\end{array}$ & $\begin{array}{l}18366640 \\
{[39]}\end{array}$ \\
\hline $\begin{array}{l}N A^{*} \\
N A^{*}\end{array}$ & $\begin{array}{l}\mathrm{C} / \mathrm{T} \\
\mathrm{G} / \mathrm{A}\end{array}$ & $\begin{array}{l}\text { Promoter } \\
\text { Exon } 1\end{array}$ & $\begin{array}{l}\text { Aspirin- } \\
\text { induced } \\
\text { urticaria/ } \\
\text { angioedema }\end{array}$ & $\begin{array}{l}15953854 \\
{[43]}\end{array}$ \\
\hline rs2606731 & $\mathrm{G} / \mathrm{T}$ & Intron 1 & $\begin{array}{l}\text { Opioid use in } \\
\text { cancer pain }\end{array}$ & $\begin{array}{l}21398039 \\
{[45]}\end{array}$ \\
\hline rs346076 & $A / G$ & Intron 1 & & $\begin{array}{l}\text { [45] } \\
21570824\end{array}$ \\
\hline $\begin{array}{l}\text { rs346070 } \\
\text { rs901865 }\end{array}$ & $\begin{array}{l}C / T \\
G / A\end{array}$ & $\begin{array}{l}\text { 3'UTR } \\
\text { 5'UTR }\end{array}$ & & [46] \\
\hline
\end{tabular}

$N A^{*}$ denotes $r$ number was not assigned and $N A^{+}$denotes $r$ s number could not be identified

\section{Human Histamine $\mathrm{H}_{2}$ Receptor}

The human histamine $\mathrm{H}_{2}$ receptor is mostly expressed in gastric parietal cells, vascular smooth muscle, suppressor T cells, neutrophils, the CNS and the heart. Its main involvement is in stimulation of gastric acid secretion and hence an important therapeutic target for gastric ulcers 
[7]. The Hisamine $\mathrm{H}_{2}$ receptor is located in Chromosome 5 and contains two introns and two exons. Similar to the $\mathrm{H}_{1}$ receptor, $\mathrm{HRH} 2$ gene has intron 1 located in the 5'-UTR region, however, this region is much smaller in length with 24,561 base pairs compared to 121,910 base pairs in the $\mathrm{H}_{1}$ receptor gene [12]. Looking into the translated amino acid sequence, this member displays a different structure when compared to the other family members (Figure 4). The receptor is characterised by a small ICL3 and a larger C-terminal with around 54 amino acids, compared to 4, 18 and 20 amino acids for $\mathrm{H}_{1}, \mathrm{H}_{3}$ aand $\mathrm{H}_{4}$ receptors, respectively.

\section{[Figure 4]}

\section{Histamine $\mathrm{H}_{2}$ polymorphisms in CNS disorders}

Human Histamine 2 receptor has also been localized in the neocortex, hippocampus, caudate and putamen regions of the brain [37]. However, studies focusing on the $\mathrm{H}_{2}$ receptor and schizophrenia so far have been controversial. The amino acid exchange of Asn217Asp was suggested to be more common in schizophrenia patients [47,48], however this could not be replicated in other studies [49]. To date no strong association has been linked between the $\mathrm{H}_{2}$ receptor and the disease, yet famotidine, a selective $\mathrm{H}_{2}$ receptor antagonist, has been successfully used to treat the negative symptoms of schizophrenia [50]. Low brain distribution of available $\mathrm{H}_{2}$ receptor antagonists/inverse agonists most probably contribute to the missing significance of data. The interactions between antipsychotics and the four histamine receptor subtypes generate an interesting perspective for the involvement of $\mathrm{HRHs}$ and the disease.

A study for the $\mathrm{H}_{2}$ polymorphism -1018-G/A was carried out on 164 patients treated with clozapine and diagnosed with schizophrenia showed a strong linkage disequilibrium (LD) between -1018G/A and -592-A/G (LD $P<10^{-6}$ ). This relationship was not observed in multiple testing possibly due to small patient sample and due to the differences in diagnostics methods employed to assess drug response. However, due to limitations in the study there could still be a potential role in patient outcome to clozapine treatment upon further studies [37]. This same polymorphism (1018-G/A) was also looked into for association with Parkinson's disease (PD), since this genetic variation lies in the promoter region of the receptor. Variations in the promotor region may contribute to changes in expression of the receptor. Nevertheless, no major risk factor was observed for the risk of PD to this SNP [39]. This promoter polymorphism was included in multiple studies which are summarized in Table 3. 


\section{Histamine $\mathrm{H}_{2}$ polymorphisms in inflammatory disorders}

The histamine $\mathrm{H}_{2}$ receptor works by suppressing inflammation by decreasing eosinophil and neutrophil chemotaxis; decreasing IL-12 by dendritic cells; increasing IL-10 and inducing the development of Th2 or tolerance-inducing dendritic cells [51]. This receptor also became pharmacologically important in gastric acid production. Studies observed that histamine-evoked gastric acid secretion were not blocked with classical antihistamines, hence, this led to the conclusion that histamine $\mathrm{H}_{2}$ receptors were involved in gastric acid secretion [52].

The same polymorphism mentioned earlier, -1018-G/A, located in the promoter region of the $\mathrm{H}_{2}$ receptor was identified to be associated with gastric mucosal atrophy [53], which is interesting considering that $\mathrm{H}_{2}$ receptor blockers are the major therapeutic strategy used against gastric acid disorders. Atrophic gastritis is a chronic inflammation in the mucosal lining and together with $H$. pylori infections, can even result in gastric cancer if left untreated [54, 55]. The GG genotype of rs2607474 proved to give a significant increase in the risk of gastric mucosal atrophy, especially in H. pylori infected patients. The minor allele frequency for the GA genotype in gastric atrophy patients compared to controls was $8.02 \%$ and $13.3 \%$ respectively $(P=0.057$ ), with the GG genotype being significantly increased in the patient group $(P=0.055)$ [53]. As a result, this polymorphism in particular seems to provide a biological marker for this condition and can be used as a tool to identify the risk and severity of gastric mucosal atrophy in combination with $H$. pylori infection.

Genetic variation on the exon of Histamine $\mathrm{H} 2$ receptor were also studied in relation to aspirin induced urticaria/angioedema. The polymorphisms located on Exon 1, G543A and C826T, however did not show any significant difference in allele and genotype frequencies of their SNPs, which indicated that these genetic variations are not related with the development of aspirin induced urticaria/angioedema phenotype [43].

\section{Histamine $\mathrm{H}_{2}$ polymorphisms in cancer}

Histamine seems to play a role in cell proliferation in malignant cells, where high histamine biosynthesis was reported in different human neoplasias [56,57]. It has been shown that $\mathrm{H}_{1}$ and $\mathrm{H}_{2}$ receptors are expressed in normal and malignant cells lines, and that $\mathrm{H}_{3}$ and $\mathrm{H}_{4}$ receptors are expressed in cell lines of human mammary gland [57]. Analysis carried out on the $\mathrm{H}_{2}$ receptor in gastric carcinoma identified promoter polymorphism rs2607474 (-1018-G/A) to be associated with 
the disease. The homozygous GG genotype was found to be associated with gastric mucosal atrophy $(P=0.0052)$ with a subsequent development of gastric cancer (mostly intestinal, $P=$ 0.0047) especially at an advanced age [58]. This polymorphism was also identified by the same group to be associated with gastric mucosal atrophy as mentioned in the previous section. And this association with gastric cancer was even higher at an advanced age where the atrophy and metaplasia scores were found to be higher [58]. Due to the location of this SNP in an important region for gene regulation, it seems like it has an important implication in gene transcription, but further analysis are needed to prove this biological significance. Another recent study also investigated the potential impact this polymorphism has in breast cancer. Two hundred and one Chinese Han women were genotyped for rs2607474, however no significant difference in the frequencies of genotypes $(P=0.174)$ or alleles $(P=0.054)$ between breast cancer patients and health controls [59]. Hence, while this SNP indicates a potential role in gastric cancer, it might not be a risk factor in breast cancer. However further investigations need to be conducted to confirm this is not ethnic or population related.

The polymorphisms rs1800689 which is located on Exon 1 (G/A; codon 181) was included in a study in UV-susceptibility in non-melanoma skin cancer. However it was concluded that there was no association between this SNP with UV-induced immunosuppression and risk of non-melanoma skin cancer [60].

The Table below (Table 3) shows all polymorphisms related to histamine $\mathrm{H}_{2}$ receptor and associated diseases.

Table 3. HRH2 polymorphisms in diseases

\begin{tabular}{|c|c|c|c|c|}
\hline rs number & SNP & $\begin{array}{l}\text { Location } \\
\text { on gene }\end{array}$ & Condition & PubMed ID \\
\hline rs2067474 & G/A & Promoter & Schizophrenia & $\begin{array}{l}12429384 \\
{[37]}\end{array}$ \\
\hline rs2067474 & G/A & Promoter & $\begin{array}{l}\text { Parkinson's } \\
\text { disease }\end{array}$ & $\begin{array}{l}18366640 \\
{[39]}\end{array}$ \\
\hline $\begin{array}{l}N A^{*} \\
N A^{*}\end{array}$ & $\begin{array}{l}G / A \\
C / T\end{array}$ & $\begin{array}{l}\text { Exon } 1 \\
\text { Exon } 1\end{array}$ & $\begin{array}{l}\text { Aspirin- } \\
\text { induced } \\
\text { urticaria/ } \\
\text { angioedema }\end{array}$ & $\begin{array}{l}15953854 \\
{[43]}\end{array}$ \\
\hline rs2607474 & G/A & Promoter & $\begin{array}{l}\text { Gastric } \\
\text { mucosal } \\
\text { atrophy }\end{array}$ & $\begin{array}{l}22720301 \\
{[53]}\end{array}$ \\
\hline
\end{tabular}




\begin{tabular}{|l|l|l|l|l|}
\hline rs1800689 & G/A & Exon 1 & $\begin{array}{l}\text { Non- } \\
\text { melanoma } \\
\text { skin cancer }\end{array}$ & $\begin{array}{l}\text { 21760883 } \\
{[60]}\end{array}$ \\
\hline rs2607474 & G/A & Promoter & $\begin{array}{l}\text { Gastric } \\
\text { cancer }\end{array}$ & $\begin{array}{l}22615049 \\
{[58]}\end{array}$ \\
& & & NA* denotes rs number was not assigned
\end{tabular}

\section{Human Histamine $\mathrm{H}_{3}$ Receptor}

The histamine $\mathrm{H}_{3}$ receptor, first cloned in 1999 by $\mathrm{J} \& \mathrm{~J}$ [3], is a presynaptic autoreceptor on histamine neurons and heteroreceptor on various neurotransmitter neurons, and is expressed in the CNS and peripheral nerves [7]. The genomic organization of this receptor is slightly different from the previous two receptors. It is similar to histamine $\mathrm{H}_{2}$ where both have two introns. Though, intron two is the largest with 1549 base pairs, unlike histamine $\mathrm{H}_{2}$ where intron one was the largest intron with 24561 base pairs. The histamine $\mathrm{H}_{3}$ gene also has three exons with exon 3 being the largest with 941 base pairs [12]. These exons are translated into amino acids forming the seven transmembrane domains with a large ICL3, similar to Histamine $\mathrm{H}_{1}$ and $\mathrm{H}_{4}$ receptors. Exon 1 translates the N-Terminal to mid of TM2, exon 2 translates to mid of TM2 to beginning of ICL2, while exon 3 of histamine $\mathrm{H}_{3}$ receptor translates into ICL2 to the C-terminal. Figure 5 shows these levels of structural organization leading to the GPCR.

[Figure 5]

\section{Histamine $\mathrm{H}_{3}$ polymorphisms in CNS disorders}

Migraine is a neurovascular disorder and histamine is thought to participate in the pathophysiology of the disease, where the frequency of migraine is more pronounced in patients with allergic diseases and an increase in histamine levels was also observed in patients susceptible to migraine attacks $[61,62]$. A polymorphism located in the third intracellular loop of histamine $\mathrm{H} 3$ receptor (A280V), which leads to the amino acid exchange from alanine to valine was found to be a risk factor for migraine [62]. The $V$ allele for this SNP was found to be higher in patients when compared to controls, and especially the genotype VV or VA was found to be $12.92 \%$ when compared to controls with $3.22 \%(P=0.001)$. This same polymorphism was also 
reported to influence the signaling of the histamine $\mathrm{H}_{3}$ receptor without affecting the binding characteristics in the Shy-Drager syndrome study. This SNP was initially noticed in one patient when HRH3 was originally cloned (shown in Table 4) [63]. This syndrome is marked with multiple system atrophy with orthostatic hypotension. In this publication a functional implication of the amino acid exchange of alanine to valine was suggested it reduces signaling efficacy in $\mathrm{H}_{3}$ receptors when expressed in $\mathrm{CHO}-\mathrm{K} 1$ cell line [64]. This was suggested to be of relevance in the pathophysiology of conditions linked to this $A / V$ mutation such as migraine and multiple system atrophy with orthostatic hypotension, however further research is needed to confirm this hypothesis [64].

This third member of the histamine family was also studied for its impact in schizophrenia. A publication by Southam et al identified a possible role for the histamine $\mathrm{H} 3$ receptor in schizophrenia. A histamine H3 receptor antagonist, GSK207040, was found to exhibit a behavioral and neurochemical profile on this receptor and beneficial to treat the cognitive and sensory gating deficits of schizophrenia [65]. The polymorphism found in exon 3, giving a C/T allele exchange was investigated in risperidone response in Chinese Han population. Strong association was identified between rs3787430 $(P=0.024,0.010)$ and a positive response to risperidone treatment in a Chinese Han population after 4 and 8 weeks respectively. This polymorphism could be a potential genetic marker for treatment. Association for rs3787429 was only noted after 4 weeks $(P=0.013)[66]$. The histaminergic system has been linked to the pathophysiology of schizophrenia and with histamine $\mathrm{H}_{3}$ receptor being mostly located in the central nervous system, will continue to encourage research in this area.

\section{Histamine $\mathrm{H}_{3}$ polymorphisms in inflammatory disorders}

Allergic asthma is an inheritable condition and many genetic variations were investigated in order to establish a link to the disease and its treatment. The histamine $\mathrm{H}_{3}$ receptor was not excluded from these investigations. The study by Ferreira et al aimed to establish a link between candidate genes and the disorder, including eight SNPs on HRH3. The SNP rs6062144, located $8 \mathrm{kbp}$ upstream to the gene was the most associated $(P=0.036)$, but there was no overall evidence for association [67]. The evidence for a strong link between asthma and histamine $\mathrm{H}_{3}$ receptor is still far from being confirmed, and as seen from Table 4, the majority of association studies between this third receptor and diseases are mostly related to CNS disorders. 
The role of histamine and histamine receptors in experimental autoimmune encephalitis has been looked into. This third histamine receptor and its polymorphisms were investigated for a potential role in multiple sclerosis pathogenesis. The functional polymorphism G293D located in the third intracellular loop of the GPCR was studied by expressing the two alleles in mice models and compare the pharmacological properties of $\mathrm{H} 3$ receptor ligands. Overall, no significant difference in affinity was observed, however, this polymorphism seems to have an impact in the $\mathrm{HRH} 3$ isoform for this receptor. This study indicates the HRH3 polymorphism isoform has a role in regulating neurogenic control in experimental autoimmune encephalitis and $\mathrm{T}$ cell response in mice [68]. With further research into this role, we might be a step closer into identifying pharmacological targets in preventing the development of new lesions in multiple sclerosis.

\section{Histamine $\mathrm{H}_{3}$ polymorphisms in cancer}

Unlike the other family members of this GPCR family, the histamine $\mathrm{H}_{3}$ receptor is less investigated in its impact in cancer. The SNPs located on this gene were genotyped in a Chinese Han population together with histamine decarboxylase (HDC) and histamine N-methytransferase (HNMT) were genotyped for an association in breast cancer. Two hundred and one patient samples were analysed for a potential role in this condition. The SNPs rs3787429 and rs3787430 were identified as the only two tag-SNPs for HRH3 gene. However, even though, as mentioned earlier these two polymorphisms were identified to contribute to risperidone treatment, no significant association was identified in the risk of breast cancer in this group [69]. Further to this finding, a larger population study would be required to omit the role of these SNPs in breast cancer.

Table 4. HRH3 polymorphisms in diseases

\begin{tabular}{|l|l|l|l|l|}
\hline rs number & SNP & $\begin{array}{l}\text { Location } \\
\text { on gene }\end{array}$ & Condition & PubMed ID \\
\hline rs3787430 & C/T & Exon 3 & Schizophrenia & $\begin{array}{l}21652606 \\
{[66]}\end{array}$ \\
rs3787429 & C/T & Exon 3 & & \\
\hline rs752380770 & C/T & Exon 3 & Migraine & $\begin{array}{c}21376262 \\
{[62]}\end{array}$ \\
& & & & \\
\hline
\end{tabular}




\begin{tabular}{|l|l|l|l|l|}
\hline rs752380770 & C/T & Exon 3 & $\begin{array}{l}\text { Shy-Drager } \\
\text { syndrome }\end{array}$ & $\begin{array}{l}23713487 \\
{[64,63]}\end{array}$ \\
\hline rs6062144 & C/G & $\begin{array}{l}\text { Upstream } \\
\text { 5'UTR }\end{array}$ & Asthma & $\begin{array}{l}19824886 \\
{[67]}\end{array}$ \\
\hline
\end{tabular}

\section{Human Histamine $\mathrm{H}_{4}$ Receptor}

Several research groups cloned and identified the new member of the histamine receptor family, the human histamine receptor $4[70,2,7,4]$. To date, only two isoforms have been identified for the $\mathrm{HRH} 4$. However when compared to the other member $\mathrm{HRH} 3,20$ naturally occurring isoforms have been identified so far, where some display differential expression patterns in various brain areas and functionalities compared with its respective full-length isoform [22]. Investigations of potential therapeutic use for this receptor are strongly related to its localization and expression. The HRH4 is preferentially expressed in various cells of the immune system and mast cells. It also induces chemotaxis of eosinophils, mast cells and monocyte-derived dendritic cells. Other involvement of $\mathrm{HRH} 4$ was also reported in the control of interleukin (IL)-16 release from human lymphocytes and it has been speculated that $\mathrm{H} 4$ selective antagonists might be useful in the treatment of asthma [70,26]. Various research groups suggest that this receptor can also be a potential therapeutic target for other inflammatory diseases, such as chronic allergy, atopic dermatitis and inflammatory bowel disease. Other possible roles for $\mathrm{HRH} 4$ are rheumatoid arthritis and colorectal cancer since this receptor has been detected in the primary synovial fluid of these tissues [70].

The HRH4 gene is located in chromosome 18 in section q11.2 close to the centromere. On comparing the four receptors, the $\mathrm{H}_{3}$ receptor and $\mathrm{H}_{4}$ receptor genes $(\mathrm{HRH} 3$ and $\mathrm{HRH} 4$, respectively) share a similar genomic organization, consisting of three exons and two introns, and in both receptors intron 2 is the largest with 7804 base pairs for $\mathrm{HRH}_{4}$ [12]. Similar to $\mathrm{H}_{1}$ and $\mathrm{H}_{4}$ receptors, the intracellular loop 3 large and is the largest for this family member. The gene, amino acid and GPCR organization are shown in Figure 6 respectively.

[Figure 6] 


\section{Histamine $\mathrm{H}_{4}$ polymorphisms in CNS disorders}

The histamine $\mathrm{H}_{4}$ receptor was also studied for associations with CNS disorders. Immunological and pharmacological studies have suggested that $\mathrm{HRH} 4$ is expressed on fibers emanating from brain regions, most likely the hippocampus or thalamus [71]. It was also suggested that it is expressed in subpopulations of neurons within the sensory dorsal root ganglia and dorsal horn of the spinal cord and in restricted cortical thalamic areas of the brain [72]. So far, the expression of $\mathrm{HRH} 4$ in the brain is still controversial. Several groups could not detect mRNA of this receptor in the CNS $[4,6]$, while other research groups reported the presence in various parts of the CNS, including amygdala, cerebellum, hippocampus, caudate nucleus, substantia nigra, thalamus and hypothalamus $[9,10]$.

Evidence was put forward for the role in the schizophrenia and this was also seen by the different binding affinity that therapeutic drugs have for this condition. Clozapine and amitriptyline were found to bind to the $\mathrm{H}_{4}$ receptor in the low micromolar range where clozapine showed partial agonism for the $\mathrm{H}_{4}$ receptor and a high binding affinity to the $\mathrm{H}_{2}$ receptor, both in a clinically relevant concentration [30]. An association study was conducted to identify a link between a polymorphism (rs4483927) with histamine $\mathrm{H}_{4}$ and the efficacy of risperidone, an antipsychotic drug used in schizophrenia. A significant association for risperidone efficacy where the TT genotype predicts poor response to treatment both on the positive, negative, and general subscales and on the total scale of PANSS scores $(P=0.017,0.019,0.021,0.002$ respectively). The SNP could be used as a biological marker for therapeutic response in personalized medicine [73].

\section{Histamine $\mathrm{H}_{4}$ polymorphisms in inflammatory disorders}

Histamine $\mathrm{H}_{1}, \mathrm{H}_{2}$ and $\mathrm{H}_{4}$ receptors are the three main receptors shown to be linked to inflammation and immune response [41]. The $\mathrm{H}_{4}$ receptor promotes the accumulation of inflammatory cells at sites of allergic inflammation by increasing calcium flux in human eosinophils; increasing eosinophil chemotaxis and increasing IL-16 production [51, 74].

The main focus for this new receptor was with inflammatory disorders. Only few genetic variations on this gene have been associated so far with asthma and underlying conditions, as shown in Table 5. These SNPs (rs17187619, rs527790, rs487202, rs1421125, rs615283) do not give a missense mutation since they are not located in an exon leading to an amino acid exchange, yet they still seem to contribute to the condition. 
Other polymorphisms found on the $\mathrm{H}_{4}$ receptor have also been linked to infections in asthma patients. The recent SNPs described in the study by Simon et al identified an association to conjunctivitis in asthma patients for the polymorphism rs615283 in the GG genotype $(P=0.008)$. An association was also identified in polymorphisms rs17187619, rs487202, rs527790 in patients with or without infection-induced asthma $(P=0.002,0.0002,0.00007$ respectively). Haplotypes from polymorphisms, rs487202 and rs574913, where the CC allele combination for these SNPs was found to be associated with infection-induced asthma $(P=0.0009)$ [75]. The CA haplotype for these polymorphisms was also more common in infection-induced asthma patients $(P=$ 0.0006). SNPs located downstream to the HRH4 gene, rs1421125, rs487202, rs527790, have shown to be linked to asthmatics with or without allergic rhinitis $(P=0.005,0.006,0.006$ respectively) [75], which enhances the concept that this receptor could play a role in this condition.

The histamine $\mathrm{H}_{4}$ receptor was also associated to allergic atopic dermatitis (AAD). This receptor has been found expressed in dendritic epithelial cells with a role in regulating histamine levels. It was suggested that $\mathrm{H}_{4}$ receptor agonists can be beneficial in downregulating inflammation in AAD [76]. One of the SNPs identified in this linkage study was rs77485247, located 51 bp upstream to the gene in the 5'UTR [41], representing the potential promoter region of the gene. A variation in this part of the gene could be responsible for gene expression [77], but further investigations need to be done to confirm. Two other polymorphisms located in exon 3 were also investigated in systemic lupus erythematosus and atopic dermatitis. The nonsense mutation of SNP rs74604924 leads to a stop codon, whereas rs77041280 results in a missense mutation leading to an amino acid exchange. These SNPs suggest a genetic linkage to Atopic Dermatitis where rs74604924 gives a functional amino acid exchange Lys376Ter[*] and rs77041280 gives an amino acid exchange Ile376Lys (rs77485247, rs74604924, rs77041280 where $P=0.002, P<0.001, P<$ 0.001, respectively) [41]. However, these SNPs were found to show no significant association between rs77485247, rs74604924, rs77041280 in lupus erythematosus $(P<0.694,0.439,0.561$ respectively) [78], however copy number variants found on the $\mathrm{H}_{4}$ receptor were identified as a significant link to the disease [78]. These copy number variations (CNVs) were recently found to be associated with Allergic Atopic Dermatitis. Variations included in the study were both deletions (CNVs less than 2) and amplifications (CNVs more than 4). Amplification on the HRH4 gene were found to be significantly associated to AAD $(P<0.05)$ whereas deletions on the HRH4 were not found to be linked to the condition $(P=0.3)$. The HRH4 mRNA levels were also found to be higher in CNV amplifications, suggesting that $\mathrm{HRH} 4$ expression is regulated by inflammatory stimuli from this autoimmune disease [79]. 
This potential linkage between SNPs to AAD, encourages studies to identify ligands that can treat or prevent this condition. The $\mathrm{H}_{4}$ receptor antagonists, JNJ7777120 and JNJ28307474, were investigated for their potential use when compared to $\mathrm{H}_{1}$ receptor antagonists, cetirizine and hydroxyzine but it was shown that there was no impact on the skin lesion prevention for AAD [80]. Interactions between $\mathrm{H}_{4}$ receptor and this antagonists, JNJ3975879, is to date the most studied and published as it is a potent selective $\mathrm{H}_{4}$ antagonist that proved effective in preclinical models of pruritus, dermatitis, asthma, and arthritis [81]. A recent study found that co-administration of histamine $\mathrm{H}_{1}$ and $\mathrm{H}_{4}$ receptor antagonists had potent inhibitory effects that were equal to those of steroids in a chronic allergic dermatitis mouse model, and JNJ39758979 exhibited anti-pruritic effects in moderate AD patients [82]. This encourages further investigations for $\mathrm{H}_{4}$ receptor antagonists in this allergic inflammatory conditions.

\section{Histamine $\mathrm{H}_{4}$ polymorphisms in cancer}

This new member of the histamine receptor family has been recently associated with malignancy of breast cancer. Evidence was shown in the analysis of genotypes and haplotypes of a Chinese Han population. This study showed that SNPs rs623590, rs11662595, rs1421125 had a significant association with the risk and malignancy of breast cancer. The $T$ allele in rs623590 had a decreased risk of breast cancer $(P=0.012)$, while $A$ allele of rs1421125 had an increased risk of cancer $(P=0.008)$ [83]. Furthermore, the haplotype C-A-A of rs623590- rs11662595rs1421125 was found to be more common in breast cancer patients $(P=0.003)$ [83]. More investigations need to be performed to understand if these results are replicable in other populations and if this association is ethnicity-based or not.

The potential link between histamine $\mathrm{H} 4$ receptor and gastric carcinoma was also studied. However, no significant difference was found between copy number variations on $\mathrm{H}_{4}$ receptor genes and patients with gastric carcinoma, but there was a substantial correlation between copy number deletions and $\mathrm{H}_{4}$ receptor down regulation. This suggests that abnormalities in $\mathrm{H}_{4}$ receptor have a potential role in histamine-mediated regulation of tumor growth in gastric cancer [84].

The summary of the polymorphisms in histamine $\mathrm{H} 4$ receptor and associated diseases are presented in Table 5 below.

Table 5. HRH4 polymorphisms in diseases 


\begin{tabular}{|c|c|c|c|c|}
\hline rs number & SNP & $\begin{array}{l}\text { Location } \\
\text { on gene }\end{array}$ & Condition & PubMed ID \\
\hline rs4483927 & $\mathrm{G} / \mathrm{T}$ & Intron 1 & Schizophrenia & $\begin{array}{l}23422377 \\
{[73]}\end{array}$ \\
\hline rs17187619 & $\mathrm{T} / \mathrm{C}$ & Intron & Asthma & $\begin{array}{l}22653292 \\
{[75]}\end{array}$ \\
\hline rs527790 & $\mathrm{G} / \mathrm{A}$ & After H4 & & \\
\hline rs487202 & $C / G$ & & & \\
\hline rs1421125 & $\mathrm{C} / \mathrm{A}$ & & & \\
\hline rs615283 & $\mathrm{G} / \mathrm{A}$ & promoter & & \\
\hline rs77485247 & $\mathrm{A} / \mathrm{T}$ & 5'UTR & $\begin{array}{l}\text { Atopic } \\
\text { dermatitis }\end{array}$ & $\begin{array}{l}20199554 \\
{[41]}\end{array}$ \\
\hline rs74604924 & $\mathrm{A} / \mathrm{T}$ & Exon 3 & & \\
\hline rs77041280 & $\mathrm{A} / \mathrm{T}$ & Exon 3 & & \\
\hline rs77485247 & $\mathrm{A} / \mathrm{T}$ & 5'UTR & $\begin{array}{l}\text { Lupus } \\
\text { erythematosus }\end{array}$ & $\begin{array}{l}20618322 \\
{[78]}\end{array}$ \\
\hline rs74604924 & $\mathrm{A} / \mathrm{T}$ & Exon 3 & & \\
\hline rs77041280 & $\mathrm{A} / \mathrm{T}$ & Exon 3 & & \\
\hline rs623590 & $\mathrm{A} / \mathrm{C} / \mathrm{T}$ & Intron 1 & Breast cancer & $\begin{array}{l}23481304 \\
{[83]}\end{array}$ \\
\hline rs16940762 & $A / G$ & Intron 1 & & \\
\hline rs11662595 & $A / G$ & Exon 3 & & \\
\hline rs1421125 & $\mathrm{A} / \mathrm{C}$ & 3'UTR & & \\
\hline
\end{tabular}

Pharmacogenetics is progressively becoming important aspect for patient's health, where the drug targets more efficiently and effectively the disease and provides personalized care. The biogenic amine histamine plays an essential role in controlling many physiological functions, both in the central nervous system (CNS) and the peripheral nervous system (PNS) [22, 70], hence genetic variation in the four receptor subtypes becomes an important focal point. The knowledge to date on polymorphisms for the histamine receptor family encourages further interest in identifying novel genetic variations that contribute to a disease; especially with the importance histamine has in biological processes. The studies mentioned in this book chapter encourage the continued quest for personalized care to patients. However, more genomic research in the context 
of on biogenic amines, here histamine, is needed to establish a direct association between diseases, biological markers and drug treatments in this new era of personalized medicine.

\section{References}

1. Consortium IH. The International HapMap Project. Nature. 2003;426(6968):789-96. doi:10.1038/nature02168.

2. Zhu Y, Michalovich D, Wu H, Tan KB, Dytko GM, Mannan IJ et al. Cloning, expression, and pharmacological characterization of a novel human histamine receptor. Mol Pharmacol. 2001;59(3):43441.

3. Lovenberg TW, Roland BL, Wilson SJ, Jiang X, Pyati J, Huvar A et al. Cloning and functional expression of the human histamine H3 receptor. Mol Pharmacol. 1999;55(6):1101-7.

4. Oda T, Morikawa N, Saito Y, Masuho Y, Matsumoto S. Molecular cloning and characterization of a novel type of histamine receptor preferentially expressed in leukocytes. J Biol Chem. 2000;275(47):36781-6. doi:10.1074/jbc.M006480200.

5. Leurs R, Chazot PL, Shenton FC, Lim HD, de Esch IJ. Molecular and biochemical pharmacology of the histamine H4 receptor. Br J Pharmacol. 2009;157(1):14-23. doi:10.1111/j.1476-5381.2009.00250.x.

6. Nguyen T, Shapiro DA, George SR, Setola V, Lee DK, Cheng R et al. Discovery of a novel member of the histamine receptor family. Mol Pharmacol. 2001;59(3):427-33.

7. Nakamura $\mathrm{T}$, Itadani H, Hidaka $\mathrm{Y}$, Ohta M, Tanaka K. Molecular cloning and characterization of a new human histamine receptor, HH4R. Biochem Biophys Res Commun. 2000;279(2):615-20. doi:10.1006/bbrc.2000.4008.

8. Morse KL, Behan J, Laz TM, West RE, Jr., Greenfeder SA, Anthes JC et al. Cloning and characterization of a novel human histamine receptor. The Journal of pharmacology and experimental therapeutics. 2001;296(3):1058-66.

9. Coge F, Guenin SP, Rique H, Boutin JA, Galizzi JP. Structure and expression of the human histamine H4receptor gene. Biochem Biophys Res Commun. 2001;284(2):301-9. doi:10.1006/bbrc.2001.4976 [doi] S0006-291X(01)94976-9 [pii].

10. Liu C, Ma X, Jiang X, Wilson SJ, Hofstra CL, Blevitt J et al. Cloning and pharmacological characterization of a fourth histamine receptor $(\mathrm{H}(4))$ expressed in bone marrow. Mol Pharmacol. 2001;59(3):420-6.

11. Garcia-Martin E, Ayuso P, Martinez C, Blanca M, Agundez JA. Histamine pharmacogenomics. Pharmacogenomics. 2009;10(5):867-83. doi:10.2217/pgs.09.26 [doi].

12. Micallef $S$, Stark $H$, Sasse A. Polymorphisms and genetic linkage of histamine receptors. Life Sci. 2013;93(15):487-94. doi:10.1016/j.lfs.2013.08.012.

13. de Esch IJ, Thurmond RL, Jongejan A, Leurs R. The histamine $\mathrm{H} 4$ receptor as a new therapeutic target for inflammation. Trends Pharmacol Sci. 2005;26(9):462-9. doi:10.1016/j.tips.2005.07.002.

14. Kottke T, Sander K, Weizel L, Schneider EH, Seifert R, Stark H. Receptor-specific functional efficacies of alkyl imidazoles as dual histamine $\mathrm{H} 3 / \mathrm{H} 4$ receptor ligands. European journal of pharmacology. 2011;654(3):200-8. doi:10.1016/j.ejphar.2010.12.033.

15. Sadek B, Alisch R, Buschauer A, Elz S. Synthesis and dual histamine $H(1)$ and $H(2)$ receptor antagonist activity of cyanoguanidine derivatives. Molecules (Basel, Switzerland). 2013;18(11):14186-202. doi:10.3390/molecules181114186.

16. Thurmond RL, Gelfand EW, Dunford PJ. The role of histamine H1 and H4 receptors in allergic inflammation: the search for new antihistamines. Nat Rev Drug Discov. 2008;7(1):41-53. 
17. Ohsawa $\mathrm{Y}$, Hirasawa $\mathrm{N}$. The antagonism of histamine $\mathrm{H} 1$ and $\mathrm{H} 4$ receptors ameliorates chronic allergic dermatitis via anti-pruritic and anti-inflammatory effects in NC/Nga mice. Allergy. 2012;67(8):1014-22. doi:10.1111/j.1398-9995.2012.02854.x.

18. Venter JC, Adams MD, Myers EW, Li PW, Mural RJ, Sutton GG et al. The sequence of the human genome. Science. 2001;291(5507):1304-51. doi:10.1126/science.1058040.

19. Bockaert J, Marin P, Dumuis A, Fagni L. The 'magic tail' of G protein-coupled receptors: an anchorage for functional protein networks. FEBS Letters. 2003;546(1):65-72. doi:http://dx.doi.org/10.1016/S00145793(03)00453-8.

20. Peeters MC, van Westen GJ, Li Q, AP IJ. Importance of the extracellular loops in G protein-coupled receptors for ligand recognition and receptor activation. Trends Pharmacol Sci. 2011;32(1):35-42. doi:10.1016/j.tips.2010.10.001.

21. ConsumerReports.org. Using the Antihistamines to Treat: Allergies, Hay Fever, \& Hives. Consumer Reports. 2013. $\quad$ https://www.consumerreports.org/health/resources/pdf/best-buydrugs/Antihistamines.pdf. Accessed 12/10/2015 2015.

22. Leurs R, Vischer HF, Wijtmans M, de Esch IJ. En route to new blockbuster anti-histamines: surveying the offspring of the expanding histamine receptor family. Trends Pharmacol Sci. 2011;32(4):250-7. doi:10.1016/j.tips.2011.02.004.

23. Proof of activity study of UR-63325 in allergic rhinitis induced by nasal challenge [database on the Internet]2011. Available from: http://clinicaltrials.gov/ct2/show/NCT01260753?term=UR63325\&rank=1. Accessed: 12/10/2015.

24. Salcedo $\mathrm{C}$, Pontes $\mathrm{C}$, Merlos $\mathrm{M}$. Is the $\mathrm{H} 4$ receptor a new drug target for allergies and asthma? Frontiers in bioscience (Elite edition). 2013;5:178-87.

25. Isberg V, Vroling B, van der Kant R, Li K, Vriend G, Gloriam D. GPCRDB: an information system for G protein-coupled receptors. Nucleic Acids Res. 2014;42(Database issue):D422-5. doi:10.1093/nar/gkt1255. 26. Parsons ME, Ganellin CR. Histamine and its receptors. Br J Pharmacol. 2006;147 Suppl 1:S127-35. doi:10.1038/sj.bjp.0706440.

27. Ito C. The role of the central histaminergic system on schizophrenia. Drug News Perspect. vol 6. Spain: 2004 Prous Science; 2004. p. 383-7.

28. Nakai T, Kitamura N, Hashimoto T, Kajimoto $Y$, Nishino N, Mita T et al. Decreased histamine H1 receptors in the frontal cortex of brains from patients with chronic schizophrenia. Biol Psychiatry. vol 4. United States1991. p. 349-56.

29. Prell GD, Green JP, Kaufmann CA, Khandelwal JK, Morrishow AM, Kirch DG et al. Histamine metabolites in cerebrospinal fluid of patients with chronic schizophrenia: their relationships to levels of other aminergic transmitters and ratings of symptoms. Schizophr Res. vol 2. Netherlands1995. p. 93-104.

30. Appl H, Holzammer T, Dove S, Haen E, Strasser A, Seifert R. Interactions of recombinant human histamine $\mathrm{H}_{1} \mathrm{R}, \mathrm{H}_{2} \mathrm{R}, \mathrm{H}_{3} \mathrm{R}$, and $\mathrm{H}_{4} \mathrm{R}$ receptors with 34 antidepressants and antipsychotics. Naunyn Schmiedebergs Arch Pharmacol. 2012;385(2):145-70. doi:10.1007/s00210-011-0704-0.

31. Salvi V, Barone-Adesi F, D'Ambrosio V, Albert U, Maina G. High H1-affinity antidepressants and risk of metabolic syndrome in bipolar disorder. Psychopharmacology (Berl). 2015. doi:10.1007/s00213-0154085-9.

32. Provensi G, Blandina P, Passani MB. The histaminergic system as a target for the prevention of obesity and metabolic syndrome. Neuropharmacology. 2015. doi:10.1016/j.neuropharm.2015.07.002.

33. Perlis RH, Adams DH, Fijal B, Sutton VK, Farmen M, Breier A et al. Genetic association study of treatment response with olanzapine/fluoxetine combination or lamotrigine in bipolar I depression. J Clin Psychiatry. 2010;71(5):599-605. doi:10.4088/JCP.08m04632gre [doi].

34. Basile VS, Masellis M, Potkin SG, Kennedy JL. Pharmacogenomics in schizophrenia: the quest for individualized therapy. Hum Mol Genet. 2002;11(20):2517-30. 
35. Vehof J, Risselada AJ, Al Hadithy AF, Burger H, Snieder H, Wilffert B et al. Association of genetic variants of the histamine $\mathrm{H} 1$ and muscarinic $\mathrm{M} 3$ receptors with $\mathrm{BMI}$ and $\mathrm{HbA1C}$ values in patients on antipsychotic medication. Psychopharmacology (Berl). 2011;216(2):257-65. doi:10.1007/s00213-011-2211-x [doi].

36. Wu R, Zhao J, Shao P, Ou J, Chang M. Genetic predictors of antipsychotic-induced weight gain: a casematched multi-gene study. Zhong nan da xue xue bao Yi xue ban = Journal of Central South University Medical sciences. 2011;36(8):720-3. doi:10.3969/j.issn.1672-7347.2011.08.003.

37. Mancama D, Arranz MJ, Munro J, Osborne S, Makoff A, Collier D et al. Investigation of promoter variants of the histamine 1 and 2 receptors in schizophrenia and clozapine response. Neurosci Lett. 2002;333(3):207-11.

38. Anichtchik OV, Rinne JO, Kalimo H, Panula P. An altered histaminergic innervation of the substantia nigra in Parkinson's disease. Experimental neurology. 2000;163(1):20-30. doi:10.1006/exnr.2000.7362.

39. García-Martín E, Ayuso P, Luengo A, Martínez C, Agúndez JA. Genetic variability of histamine receptors in patients with Parkinson's disease. BMC Med Genet. 2008;9:15. doi:10.1186/1471-2350-9-15.

40. Pino-Ángeles A, Reyes-Palomares A, Melgarejo E, Sánchez-Jiménez F. Histamine: an undercover agent in multiple rare diseases? J Cell Mol Med. 2012;16(9):1947-60. doi:10.1111/j.1582-4934.2012.01566.x.

41. Yu B, Shao Y, Zhang J, Dong XL, Liu WL, Yang H et al. Polymorphisms in human histamine receptor H4 gene are associated with atopic dermatitis. Br J Dermatol. 2010;162(5):1038-43. doi:10.1111/j.13652133.2010.09675.x.

42. Zampeli $\mathrm{E}$, Tiligada $\mathrm{E}$. The role of histamine $\mathrm{H} 4$ receptor in immune and inflammatory disorders. $\mathrm{Br} \mathrm{J}$ Pharmacol. 2009;157(1):24-33. doi:10.1111/j.1476-5381.2009.00151.x.

43. Choi JH, Kim SH, Suh $\mathrm{CH}, \mathrm{Nahm} \mathrm{DH}$, Park HS. Polymorphisms of high-affinity IgE receptor and histamine-related genes in patients with ASA-induced urticaria/angioedema. J Korean Med Sci. 2005;20(3):367-72.

44. Wang M, Wei X, Shi L, Chen B, Zhao G, Yang H. Integrative genomic analyses of the histamine $\mathrm{H} 1$ receptor and its role in cancer prediction. Int J Mol Med. 2014;33(4):1019-26. doi:10.3892/ijmm.2014.1649.

45. Klepstad P, Fladvad T, Skorpen F, Bjordal K, Caraceni A, Dale O et al. Influence from genetic variability on opioid use for cancer pain: a European genetic association study of 2294 cancer pain patients. Pain. 2011;152(5):1139-45. doi:S0304-3959(11)00078-9 [pii] 10.1016/j.pain.2011.01.040 [doi].

46. Laugsand EA, Fladvad T, Skorpen F, Maltoni M, Kaasa S, Fayers $P$ et al. Clinical and genetic factors associated with nausea and vomiting in cancer patients receiving opioids. Eur J Cancer. 2011;47(11):168291. doi:10.1016/j.ejca.2011.04.014.

47. Orange PR, Heath PR, Wright SR, Pearson RC. Allelic variations of the human histamine H2 receptor gene. Neuroreport. 1996;7(7):1293-6.

48. Orange PR, Heath PR, Wright SR, Ramchand CN, Kolkeiwicz L, Pearson RC. Individuals with schizophrenia have an increased incidence of the H2R649G allele for the histamine H2 receptor gene. Molecular psychiatry. 1996;1(6):466-9.

49. Ito C, Morisset S, Krebs MO, Olie JP, Loo H, Poirier MF et al. Histamine H2 receptor gene variants: lack of association with schizophrenia. Molecular psychiatry. 2000;5(2):159-64.

50. Rosse RB, Kendrick K, Tsui LC, Fay-McCarthy M, Collins JP, Rosenberg P et al. Famotidine adjunctive pharmacotherapy of schizophrenia: a case report. Clin Neuropharmacol. 1995;18(4):369-74.

51. Akdis CA, Simons FE. Histamine receptors are hot in immunopharmacology. Eur J Pharmacol. vol 1-3. Netherlands2006. p. 69-76.

52. Alonso N, Zappia CD, Cabrera M, Davio CA, Shayo C, Monczor F et al. Physiological implications of biased signaling at histamine $\mathrm{H} 2$ receptors. Frontiers in pharmacology. 2015;6:45. doi:10.3389/fphar.2015.00045. 
53. Yamada H, Tahara T, Shiroeda H, Hayashi R, Saito T, Nakamura M et al. Effects of $-1018 G>A$ polymorphism of HRH2 (rs2607474) on the severity of gastric mucosal atrophy. J Gastrointestin Liver Dis. 2012;21(2):139-43.

54. Sande N, Nikulin M, Nilsson I, Wadstrom T, Laxen F, Harkonen M et al. Increased risk of developing atrophic gastritis in patients infected with CagA+ Helicobacter pylori. Scandinavian journal of gastroenterology. 2001;36(9):928-33.

55. Ebule I, Longdoh A, Paloheimo I. Helicobacter pylori infection and atrophic gastritis. African health sciences. 2013;13(1):112-7. doi:10.4314/ahs.v13i1.15.

56. Rivera ES, Cricco GP, Engel NI, Fitzsimons CP, Martin GA, Bergoc RM. Histamine as an autocrine growth factor: an unusual role for a widespread mediator. Seminars in cancer biology. 2000;10(1):15-23.

57. Medina VA, Brenzoni PG, Lamas DJ, Massari N, Mondillo C, Nunez MA et al. Role of histamine H4 receptor in breast cancer cell proliferation. Frontiers in bioscience (Elite edition). 2011;3:1042-60.

58. Arisawa T, Tahara T, Ozaki K, Matsue Y, Minato T, Yamada $\mathrm{H}$ et al. Association between common genetic variant of HRH2 and gastric cancer risk. International journal of oncology. 2012;41(2):497-503. doi:10.3892/ijo.2012.1482.

59. Cai WK, Zhang JB, Wang NM, Wang YL, Zhao CH, Lu J et al. Lack of Association between rs2067474 Polymorphism in Histamine Receptor H2 Gene and Breast Cancer in Chinese Han Population. TheScientificWorldJournal. 2015;2015:545292. doi:10.1155/2015/545292.

60. Welsh MM, Karagas MR, Kuriger JK, Houseman A, Spencer SK, Perry AE et al. Genetic determinants of UV-susceptibility in non-melanoma skin cancer. PLoS One. 2011;6(7):e20019. doi:10.1371/journal.pone.0020019.

61. Gupta S, Nahas SJ, Peterlin BL. Chemical mediators of migraine: preclinical and clinical observations. Headache. 2011;51(6):1029-45. doi:10.1111/j.1526-4610.2011.01929.x.

62. Millán-Guerrero RO, Baltazar-Rodríguez LM, Cárdenas-Rojas MI, Ramírez-Flores M, Isais-Millán S, Delgado-Enciso I et al. A280V polymorphism in the histamine $\mathrm{H} 3$ receptor as a risk factor for migraine. Arch Med Res. 2011;42(1):44-7. doi:10.1016/j.arcmed.2011.01.009.

63. Wiedemann P, Bönisch H, Oerters F, Brüss M. Structure of the human histamine H3 receptor gene (HRH3) and identification of naturally occurring variations. J Neural Transm. 2002;109(4):443-53. doi:10.1007/s007020200036.

64. Flores-Clemente C, Osorio-Espinoza A, Escamilla-Sanchez J, Leurs R, Arias JM, Arias-Montano JA. A single-point mutation (Ala280Val) in the third intracellular loop alters the signalling properties of the human histamine $\mathrm{H}$ receptor stably expressed in CHO-K1 cells. Br J Pharmacol. 2013. doi:10.1111/bph.12257.

65. Southam E, Cilia J, Gartlon JE, Woolley ML, Lacroix LP, Jennings CA et al. Preclinical investigations into the antipsychotic potential of the novel histamine H3 receptor antagonist GSK207040. Psychopharmacology (Berl). 2009;201(4):483-94. doi:10.1007/s00213-008-1310-9.

66. Wei Z, Wang L, Zhang M, Xuan J, Wang Y, Liu B et al. A pharmacogenetic study of risperidone on histamine $\mathrm{H} 3$ receptor gene $(\mathrm{HRH} 3)$ in Chinese Han schizophrenia patients. J Psychopharmacol. 2012;26(6):813-8. doi:10.1177/0269881111405358.

67. Ferreira MA, Zhao ZZ, Thomsen SF, James M, Evans DM, Postmus PE et al. Association and interaction analyses of eight genes under asthma linkage peaks. Allergy. 2009;64(11):1623-8. doi:10.1111/j.13989995.2009.02091.x.

68. Krementsov DN, Wall EH, Martin RA, Subramanian M, Noubade R, Del Rio R et al. Histamine H(3) receptor integrates peripheral inflammatory signals in the neurogenic control of immune responses and autoimmune disease susceptibility. PLoS One. 2013;8(7):e62743. doi:10.1371/journal.pone.0062743.

69. He GH, Lin JJ, Cai WK, Xu WM, Yu ZP, Yin SJ et al. Associations of polymorphisms in histidine decarboxylase, histamine $\mathrm{N}$-methyltransferase and histamine receptor $\mathrm{H} 3$ genes with breast cancer. PLoS One. 2014;9(5):e97728. doi:10.1371/journal.pone.0097728. 
70. Lim HD, Adami M, Guaita E, Werfel T, Smits RA, de Esch IJ et al. Pharmacological characterization of the new histamine H4 receptor agonist VUF 8430. Br J Pharmacol. 2009;157(1):34-43. doi:10.1111/j.14765381.2009.00200.x.

71. Connelly WM, Shenton FC, Lethbridge N, Leurs R, Waldvogel HJ, Faull RL et al. The histamine H4 receptor is functionally expressed on neurons in the mammalian CNS. Br J Pharmacol. 2009;157(1):55-63. doi:10.1111/j.1476-5381.2009.00227.x.

72. Strakhova MI, Nikkel AL, Manelli AM, Hsieh GC, Esbenshade TA, Brioni JD et al. Localization of histamine $\mathrm{H} 4$ receptors in the central nervous system of human and rat. Brain Res. 2009;1250:41-8. doi:10.1016/j.brainres.2008.11.018.

73. Wei Z, Wang L, Yu T, Wang Y, Sun L, Wang T et al. Histamine H4 receptor polymorphism: a potential predictor of risperidone efficacy. Journal of clinical psychopharmacology. 2013;33(2):221-5. doi:10.1097/JCP.0b013e318283963b.

74. Jutel M, Watanabe T, Akdis M, Blaser K, Akdis CA. Immune regulation by histamine. Curr Opin Immunol. vol 6. England2002. p. 735-40.

75. Simon T, Semsei AF, Ungvári I, Hadadi E, Virág V, Nagy A et al. Asthma endophenotypes and polymorphisms in the histamine receptor HRH4 gene. Int Arch Allergy Immunol. 2012;159(2):109-20. doi:10.1159/000335919.

76. Dijkstra D, Stark H, Chazot PL, Shenton FC, Leurs R, Werfel T et al. Human inflammatory dendritic epidermal cells express a functional histamine H4 receptor. J Invest Dermatol. 2008;128(7):1696-703. doi:10.1038/sj.jid.5701250.

77. Brouwer JR, Willemsen R, Oostra BA. Microsatellite repeat instability and neurological disease. Bioessays. 2009;31(1):71-83. doi:10.1002/bies.080122 [doi].

78. Yu B, Shao Y, Li P, Zhang J, Zhong Q, Yang H et al. Copy number variations of the human histamine $\mathrm{H} 4$ receptor gene are associated with systemic lupus erythematosus. Br J Dermatol. 2010;163(5):935-40. doi:10.1111/j.1365-2133.2010.09928.x.

79. Chen B, Ye T, Shao Y, Zhang J, Zhong Q, Hu X et al. Association between copy-number variations of the human histamine $\mathrm{H} 4$ receptor gene and atopic dermatitis in a Chinese population. Clinical and experimental dermatology. 2013;38(3):295-300; quiz -1. doi:10.1111/ced.12117.

80. Baumer W, Stahl J, Sander K, Petersen LJ, Paps J, Stark H et al. Lack of preventing effect of systemically and topically administered histamine $\mathrm{H}(1)$ or $\mathrm{H}(4)$ receptor antagonists in a dog model of acute atopic dermatitis. Experimental dermatology. 2011;20(7):577-81. doi:10.1111/j.1600-0625.2011.01268.x.

81. Thurmond RL. The histamine H4 receptor: from orphan to the clinic. Frontiers in pharmacology. 2015;6:65. doi:10.3389/fphar.2015.00065.

82. Ohsawa $\mathrm{Y}$, Hirasawa $\mathrm{N}$. The role of histamine $\mathrm{H} 1$ and $\mathrm{H} 4$ receptors in atopic dermatitis: from basic research to clinical study. Allergology international : official journal of the Japanese Society of Allergology. 2014;63(4):533-42. doi:10.2332/allergolint.13-RA-0675.

83. He GH, Lu J, Shi PP, Xia W, Yin SJ, Jin TB et al. Polymorphisms of human histamine receptor H4 gene are associated with breast cancer in Chinese Han population. Gene. 2013;519(2):260-5. doi:10.1016/j.gene.2013.02.020.

84. Zhang C, Xiong Y, Li J, Yang Y, Liu L, Wang W et al. Deletion and down-regulation of HRH4 gene in gastric carcinomas: a potential correlation with tumor progression. PLoS One. 2012;7(2):e31207. doi:10.1371/journal.pone.0031207.

85. McWilliam H, Li W, Uludag M, Squizzato S, Park YM, Buso N et al. Analysis Tool Web Services from the EMBL-EBI. Nucleic Acids Res. 2013;41(Web Server issue):W597-600. doi:10.1093/nar/gkt376. 
Figure 1. Protein sequences alignment between $\boldsymbol{H}_{1}$ receptor and $\boldsymbol{H}_{2}$ receptor. Yellow highlighted sequences refer to the seven transmembrane domains. The dark grey indicates the conserved domains and the light grey refers to similarities between amino acids between the two GPCRs. (*) indicates positions which have a single, fully conserved residue. (:) indicates conservation between groups of strongly similar properties. (.) indicates conservation between groups of weakly similar properties.[85]

Figure 2. Protein sequences alignment between $\mathrm{H}_{3}$ receptor and $\mathrm{H}_{4}$ receptor. Yellow highlighted sequences refer to the seven transmembrane domains. The dark grey indicates the conserved domains and the light grey refers to similarities between amino acids between the two GPCRs. $\left(^{\star}\right)$ indicates positions which have a single, fully conserved residue. (:) indicates conservation between groups of strongly similar properties. (.) indicates conservation between groups of weakly similar properties.[85]

Figure 3. Histamine $\boldsymbol{H}_{1}$ Receptor molecular organization. (A) Genomic organization of HRH1. (B) Amino acid organization; where TM is transmembrane domain, ICL is intracellular loop and ECL is extracellular loop. (C) GPCR snake plot.

Figure 4. Histamine $\mathrm{H}_{2}$ Receptor molecular organization. (A) Genomic organization of HRH2. (B) Amino acid organization; where TM is transmembrane domain, ICL is intracellular loop and ECL is extracellular loop. (C) GPCR snake plot.

Figure 5. Histamine $\boldsymbol{H}_{3}$ Receptor molecular organization. (A) Genomic organization of HRH3. (B) Amino acid organization; where TM is transmembrane domain, ICL is intracellular loop and ECL is extracellular loop. (C) GPCR snake plot.

Figure 6. Histamine $\mathrm{H}_{4}$ Receptor molecular organization. (A) Genomic organization of HRH4. (B) Amino acid organization; where TM is transmembrane domain, ICL is intracellular loop and ECL is extracellular loop. (C) GPCR snake plot. 
HRH1 HUMAN

$\mathrm{HRH} 2$ _HUMAN

HRH1 HUMAN

$\mathrm{HRH} 2$ - HUMAN

HRH1 HUMAN

HRH2 2 HUMAN

HRH1_HUMAN

HRH2 HUMAN

HRH1_HUMAN

HRH2_HUMAN

HRH1 HUMAN

$\mathrm{HRH} 2$ _HUMAN

HRH1 HUMAN

HRH2_HUMAN

HRH1 HUMAN

HRH2_HUMAN

HRH1_HUMAN

HRH2_HUMAN

HRH1_HUMAN

HRH2 HUMAN
MSLPNS---SCLLEDKMCEGNKTTMASPQLMP LVVLSTICLVTVGLNLLVLYAVRSERK

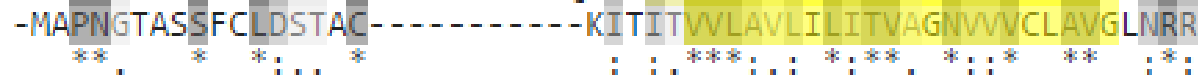

\section{LHTVG LYIVSLSVADLIVGAVVMPMNILYLLMSKWSLGRPLCLFWLSWDYVASTASIFS}

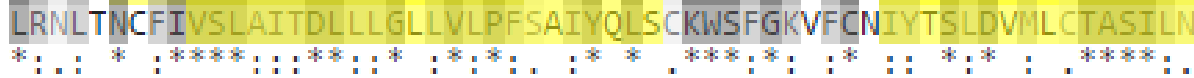

VFILCIDRYRSVQOPLRYLKYRTKTRASATILGANFLSFL - -WVIPILGWNHFMOQTS -V LFMISLDRYCAVMDPLRYPVLVTPVRVAISLVLIWVISITLSFLSIHLGWN SRNETSKGN $:^{*}:::^{* * *}:^{*}:^{* * * *} * 0^{*} .::: *^{*} .:^{*}: \quad:: *^{* * *} \quad: \quad:$

RREDKCETDFYDVTWFKVIITAIIN FYLPT LLFLWFY AKIYKAVROHCQHRELINRSLPSF HTTSKCKVQVN--EVYGLVDGLVTFYLPLLIMCITYYRIFKVARDQAKRI - - - - - - -

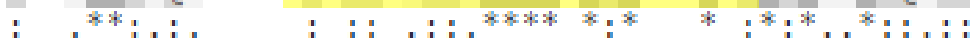

SEIKLRPENPKGDAKKPGKESPWEVLKRKPKDAGGGSVLKSPSQTPKEMKSPVVFSQEDD $-\mathrm{NHISS}-$

\section{REVDKLYCFPLDIVHMQAAAEGSSRDYVAVNRSHGQLKTDEQGLNTHGASEISEDQMLGD}

SQSFSRTDSDTTTETAPGKGKLRSGSNTGLDYIKFTWKRLRSHSRQYVSGLHMNRERKAA - WKA -

KQLGFIMAAFILCWIPYFIFFVIAFC-KNCCNEHLHMFTIWLGYINSTLNPLIYPLCNE VTLAAVMGAFIICWFPYFTAFVYRGLRGDDAINEVLEAIVLWLGYANSALNPILYAALNR

NFKKTFKRILHIRS-1.-1 DFRTGYQQLFCCRLANRNSHKTSLRSNASQLSRTQSREPRQQEEKPLKLQVWSGTEVTAP

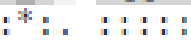


HRH3 HUMAN

HRH4_HUMAN

HRH3 HUMAN

$\mathrm{HRH} 4$ HUMAN

HRH3 HUMAN HRH4_HUMAN

HRH3 HUMAN $\mathrm{HRH} 4$-HUMAN

HRH3 HUMAN

$\mathrm{HRH} 4$-HUMAN

HRH3_HUMAN $\mathrm{HRH} 4$-HUMAN

HRH3 HUMAN HRH4_HUMAN

HRH3 HUMAN HRH4_HUMAN
MERAPPDGPLNASGALAGEAAAAGGARGFSAAWTAVLAALMALLIVATVLGNALVMLAFV

-MPDTNSTINLSLSTRVTLAFFMSLVAFAIMLGNALVILAFV $\therefore:^{*}: .^{* *}:^{*}:^{*}: .^{*}:^{* * * * * *}:^{* * * *}$

61 ADSSLRTQNNFFLLNLAISDFLVGAFCIPLYVPYVLTGWTFGRGLCKLWLVVDYLLCTS

42 VDKNLRHRSSYFFLINLAISDFFVGVISIPLYIPHTLF-EWDFGKEICVFILTTDYLLCTA

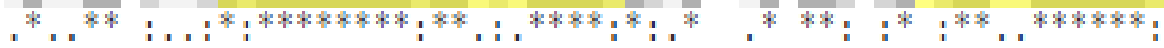

121 SAFNIVLISYDRFLSVTRAVSYRAQOGDTRRAVRKMLLVWVLAFLLYGPAILSWEYLSGG 180 101 SVYNIVLISYDRYLSVSNAVSYRTQHTGVLKIVTLMVAVWVLAFLVNGPMILVSESWKD-

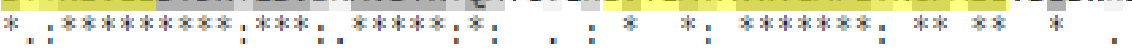

181 SSIPEGHCYAEFFYNWYFLITASTLEFFTPFLSVTFFNLSIYLNIQRRTRLRLDGAREAA 160 - - -EGSECEPGFFSEWYILAITSFLEFVIPVILVAYFNMNIYWSLWKRDHLSRCQSHP- ..

$$
{ }^{* *}:^{* *}:^{*}:^{* * * *},{ }^{*},:^{*}::^{* *}: .^{* *} .::^{*}:^{*} \quad::
$$

241 GPEPPPEAQPSPPPPPGCWGCWQKGHGEAMPLHRYGVGEAAVGAEAGEATLGGGGGGGSV

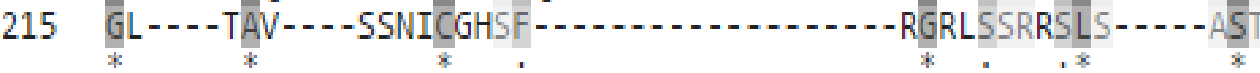

301 ASPTSSSGSSSRGTERPRSLKRGSKPSASSASLEKRMKM-- - - -VSQSFTQRFRLSRDR

355 KVAKSLAVIVSIFGLCWAPYTLLMIIRAACHG-HCVPDYWYETSFWLLWANSAVNPVLYA 


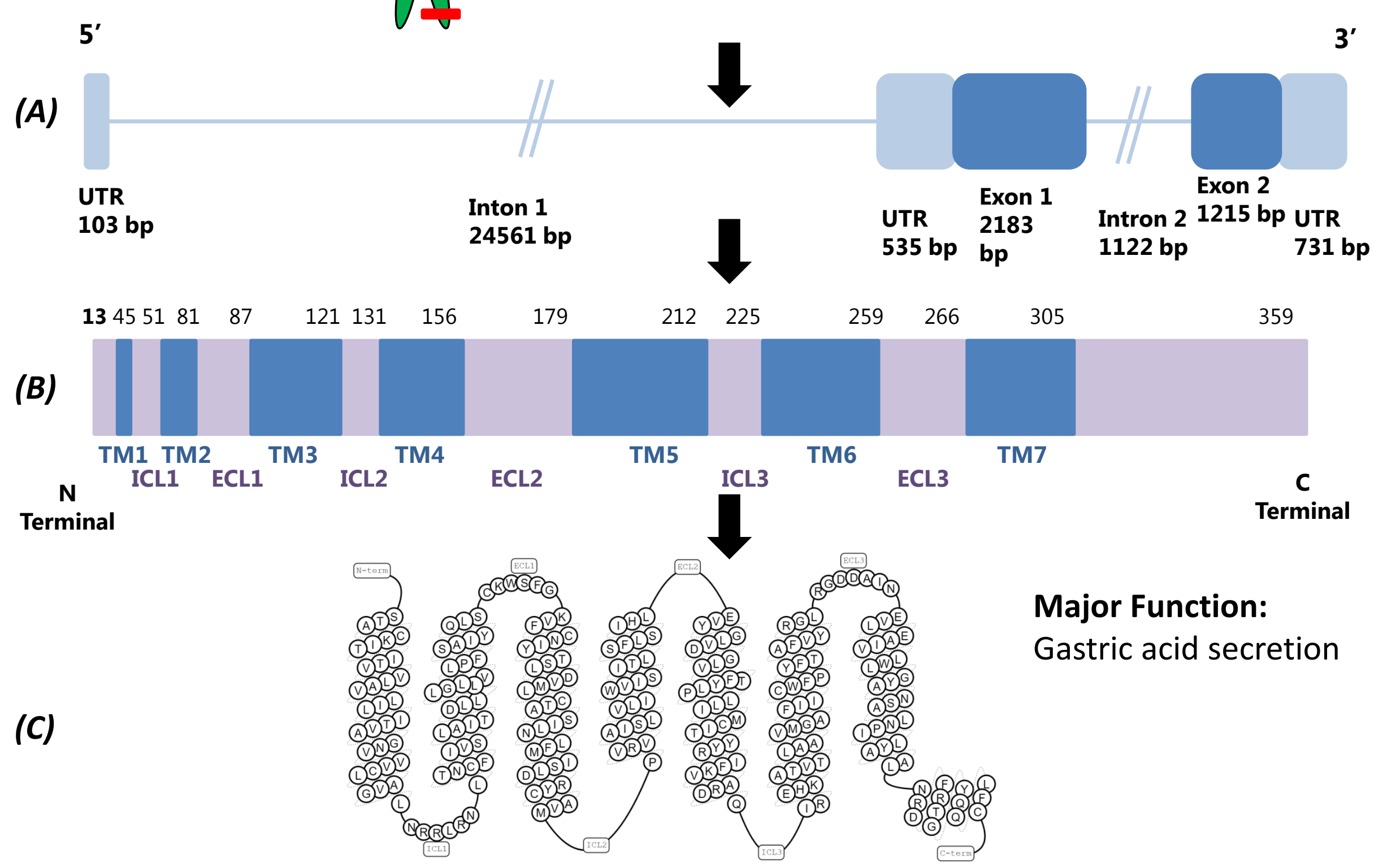


Chromosome : 20

Location: 20q13.33

\section{$\mathrm{H}_{3}$ Receptor}

Amino acids: 445

Protein: 49 kDa

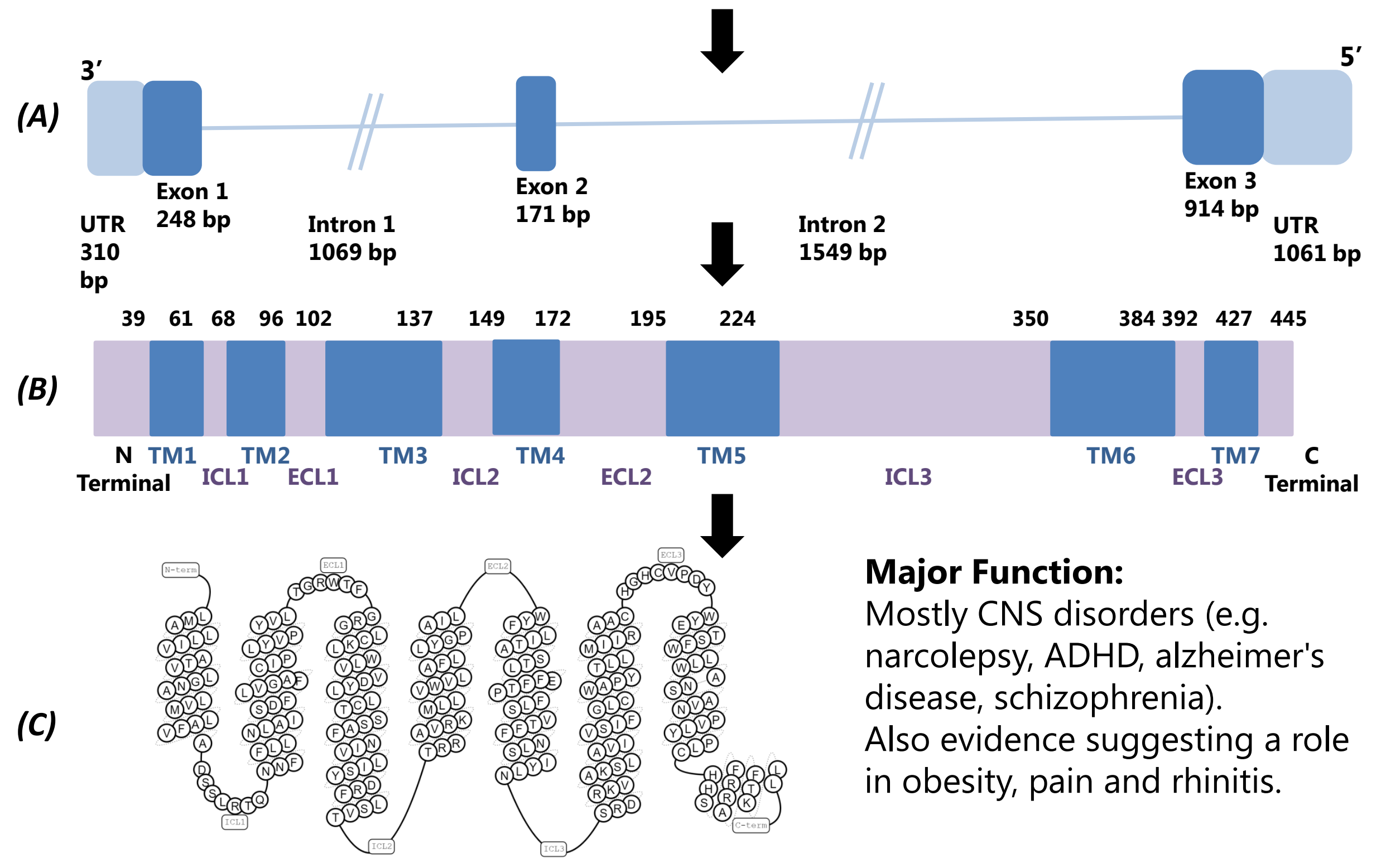




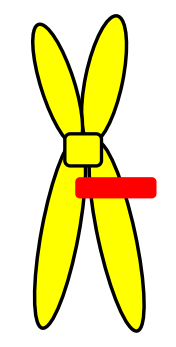

Chromosome: 18

Location: $18 q 11.2$

\section{$\mathrm{H}_{4}$ Receptor}

Amino acids: 390

Protein: 44 kDa

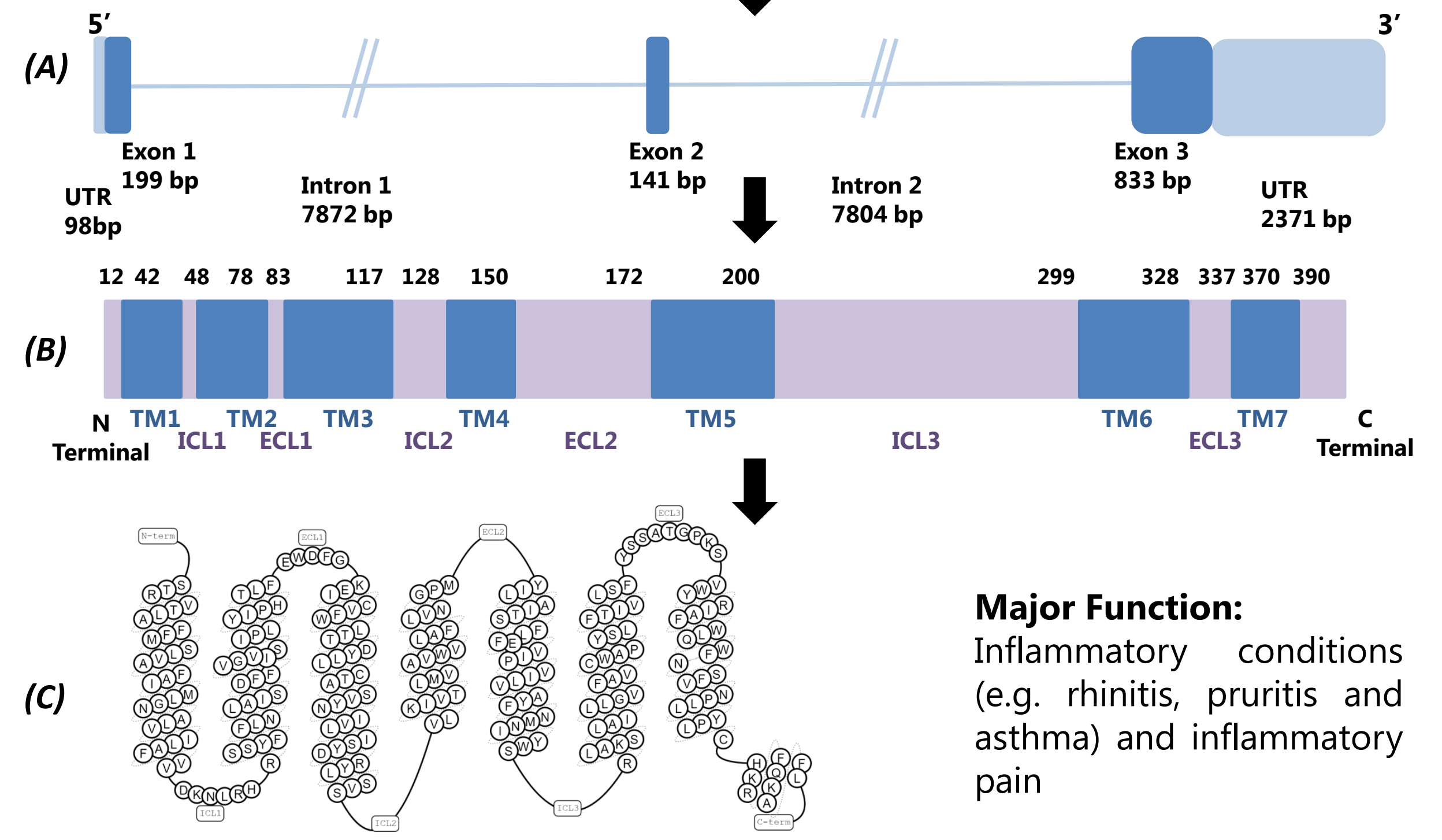

